\title{
PENGARUH DISIPLIN DAN KEPUASAN KERJA TERHADAP MOTIVASI KERJA DAN DAMPAKNYA TERHADAP KINERJA PEGAWAI DI KANTOR PELAYANAN PAJAK PRATAMA MEDAN PETISAH
}

\author{
Dedi Kurnia \\ Uiniversitas Islam Sumatera Utara \\ dedikurnia@gmail.com
}

\begin{abstract}
The formulation of the problem in this research is how the influence of dicipline on work motivation. Influence of job satisfaction on work motivation. Influence of dicipline on performance. Influence of job satisfaction on performance. Influence of work motivation on performance.The purpose of this research is for know influence and analize of dicipline on work motivation. For know influence and analize of job satisfaction on work motivation. For know influence and analize of dicipline on performance. For know influence and analize of job satisfaction on performance. For know influence and analize of work motivation on performance. The sample in this research is 88 employees, with data analysis technique used is multiple linear regression analyze. The results of this research explain that dicipline effect has a positive and significant on work motivation. Job satisfaction effect has a positive and significant on work motivation. Dicipline effect has a positive and significant on performance. Job satisfaction effect has a positive and significant on performance. Work motivation effect has a positive and significant on performance
\end{abstract}

Keywords : Dicipline, Job satisfaction, Motivation, Loyalty

\begin{abstract}
ABSTRAK : Rumusan masalah dalam penelitian ini adalah bagaimana pengaruh disiplin terhadap motivasi kerja. Bagaimana pengaruh kepuasan kerja terhadap motivasi kerja. Bagaimana pengaruh disiplin terhadap kinerja. Bagaimana pengaruh kepuasan kerja terhadap kinerja. Bagaimana pengaruh motivasi kerja terhadap kinerja. Tujuan penelitian ini adalah untuk mengetahui dan menganalisis pengaruh disiplin terhadap motivasi kerja. Untuk mengetahui dan menganalisis pengaruh kepuasan kerja terhadap motivasi kerja. Untuk mengetahui dan menganalisis pengaruh disiplin terhadap kinerja. Untuk mengetahui dan menganalisis pengaruh kepuasan kerja terhadap kinerja. Untuk mengetahui dan menganalisis pengaruh motivasi kerja terhadap kinerja.

Sampel dalam penelitian ini berjumlah 88 orang pegawai. Teknik analisis data dalam penelitian ini menggunakan analisis deskriptif dan analisis regresi linier berganda. Hasil penelitian ini menjelaskan bahwa disiplin berpengaruh positif dan signifikan terhadap motivasi kerja. Kepuasan kerja berpengaruh positif dan signifikan terhadap motivasi kerja pegawai. Disiplin berpengaruh positif dan signifikan terhadap kinerja. Kepuasan kerja berpengaruh positif dan signifikan terhadap kinerja. Motivasi kerja berpengaruh positif dan signifikan terhadap kinerja.
\end{abstract}

Kata Kunci : Disiplin, Kepuasan kerja, Motivasi Kerja, Kinerja Pegawai

\section{Pendahuluan}

Pentingnya peranan sumber daya manusia dalam mewujudkan keselarasan visi dan misi organisasi perlu diimbangi dengan kemampuan organisasi dalam menetapkan nilai-nilai yang mengarah pada tingginya tingkat kenyamanan pegawai terhadap organisasi. Salah satu alasan yang membuat sumber daya manusia memiliki suatu keunikan tersendiri disamping faktorfaktor lainnya sebagai penunjang keberlangsungan sebuah organisasi karena manusia memiliki akal, perasaan, keinginan, kemampuan, keterampilan, pengetahuan, dorongan, daya, dan karya yang berbeda-beda antara satu orang dengan orang lainnya. Tujuan organisasi tidak akan terwujud apabila tidak memperhatikan aspek-aspek yang dimiliki sumber daya manusia tersebut, secanggih apapun alat, mesin, dan faktor lain yang tersedia pada organisasi. Didalam organisasi, perbedaan-perbedaan tersebut selayaknya dapat diorganisir agar mampu menciptakan sebuah kerjasama tim dalam melewati perubahan pada era globalisasi saat ini.

Calquit (2009:113), menjelaskan kinerja dapat diartikan sebagai prestasi kerja atau hasil 
kerja (output) baik kualitas maupun kuantitas yang dicapai pegawai per periode dalam melaksanakan tugasnya sesuai dengan tanggungjawab yang diberikan kepadanya. Rivai (2008:155) menyatakan kinerja merupakan hasil kerja yang dapat dicapai oleh seseorang atau sekelompok orang dalam suatu organisasi, sesuai dengan wewenang dan tanggungjawab masing-masing dalam rangka upaya mencapai tujuan organisasi bersangkutan secara legal, tidak melanggar hukum dan sesuai dengan moral dan etika. Dengan demikian dapat dikatakan bahwa kinerja adalah prestasi kerja seseorang, baik secara kuantitas maupun secara kualitas. Permasalahan kinerja pegawai Kantor Pelayanan Pajak Pratama Medan Petisah pada saat ini masih perlu perhatian, hal ini dapat dilihat dari target pajak yang belum terpenuhi sesuai harapan.

Seorang yang memiliki motivasi yang rendah mereka cenderung untuk memperlihatkan upaya yang tidak maksimal dalam melaksanakan pekerjaannya, sehingga semakin tinggi motivasi yang dimiliki oleh individu sebagai pegawai maka dapat meningkatkan kinerja pegawai itu sendiri. Dengan demikian, setiap organisasi perlu mengetahui apa yang menjadi motivasi para pegawainya, sebab faktor tersebut dapat menjadi salah satu faktor yang menentukan tinggi atau rendahnya motivasi seorang pegawai dalam melaksanakan pekerjaan. Fakta yang ditemukan pada pegawai Kantor Pelayanan Pajak Pratama Medan Petisah menunjukkan bahwa masih ada pegawai yang terlambat masuk kerja dan masih ada pegawai yang pulang sebelum jam kerja serta masih ada pegawai yang memperpanjang jam istirahat. Walaupun Kantor Pelayanan Pajak Pratama Medan Petisah telah menerapkan peraturan yang begitu ketat tentang absensi, namun kenyataan di lapangan masih terjadi juga pelanggaran seperti yang terungkap pada fenomena diatas.

Menurut Hasibuan (2008:193), menyatakan bahwa disiplin adalah kesadaran dan ketaatan seseorang terhadap peraturan organisasi/instansi dan norma sosial yang berlaku. Dari beberapa pendapat itu dapat disimpulkan bahwa disiplin kerja adalah sikap ketaatan dan kesetiaan pegawai terhadap peraturan tertulis/tidak tertulis yang tercermin dalam bentuk tingkah laku dan perbuatan pada suatu organisasi untuk mencapai tujuan tertentu. Tujuan disiplin baik kolektif maupun perorangan yang sebenarnya adalah untuk mengarahkan tingkah laku pada realita yang harmonis. Fenomena disiplin pegawai Kantor Pelayanan Pajak Pratama Medan Petisah saat ini dapat dikategorikan cukup baik, akan tetapi masih ada juga pegawai yang melanggar peraturan yang telah diterapkan oleh kantor pajak seperti masih ada pegawai yang masih menunda pekerjaan yang diperintahkan atasan.

Faktor lain yang dapat meningkatkan kinerja pegawai Kantor Pelayanan Pajak Pratama Medan Petisah yaitu kepuasan kerja. Fenoma yang terjadi tentang kepuasan kerja pegawai Kantor Pelayanan Pajak Pratama Medan Petisah diantaranya masih ada pembagian tugas yang belum merata ke bawahan dari atasan sehingga menimbulkan ketidakpuasan pegawai.

Adapun Tujuan dari penelitian ini adalah :

a. Untuk mengetahui dan menganalisis pengaruh disiplin terhadap motivasi kerja pegawai Kantor Pelayanan Pajak Pratama Medan Petisah.

b. Untuk mengetahui dan menganalisis pengaruh kepuasan kerja terhadap motivasi kerja pegawai Kantor Pelayanan Pajak Pratama Medan Petisah.

c. Untuk mengetahui dan menganalisis pengaruh disiplin terhadap kinerja pegawai Kantor Pelayanan Pajak Pratama Medan Petisah.

d. Untuk mengetahui dan menganalisis pengaruh kepuasan kerja terhadap kinerja pegawai Kantor Pelayanan Pajak Pratama Medan Petisah.

e. Untuk mengetahui dan menganalisis pengaruh motivasi kerja terhadap kinerja pegawai Kantor Pelayanan Pajak Pratama Medan Petisah.

\section{METODE PENELITIAN \\ 2.1. Lokasi Penelitian}

Penelitian ini dilakukan di Kantor Pelayanan Pajak Pratama Medan Petisah. Jalan Asrama No. 7A Sikambing C II Medan.

\subsection{Populasi}

Menurut Sugiyono (2004:90) populasi adalah wilayah generasi yang terdiri dari atas objek/subjek yang mempunyai kualitas karakteristik tertentu yang disajikan oleh peneliti untuk dipelajari dan kemudian ditarik kesimpulannya. Berdasarkan defenisi tersebut, maka populasi dalam penelitian ini adalah para pegawai Kantor Pelayanan Pajak Pratama Medan Petisah yang berjumlah 113 orang, 
dimana Kepala Kantor dan peneliti tidak dimasukkan sebagai populasi dengan rincian sebagai berikut :

\subsection{Sampel}

Untuk menentukan jumlah sampel, digunakan pendapat Slovin dalam Sekaran dan Bougie (2010:112) dengan menggunakan formula sebagai berikut :

Keterangan :

$$
n=\frac{N}{1+N \mathrm{e}^{2}}
$$

n : Jumlah Sampel

$\mathrm{N}$ : Jumlah Populasi

$e$ : Kesalahan yang ditolerir dalam penarikan sampel yaitu 0,05 .

\subsection{Definisi Operasional Variabel}

\section{Tabel 1}

Definisi Operasional Variabel

\begin{tabular}{|c|c|c|c|c|}
\hline No & Definisi & Variabel & Indikator Pengukuran & Skala \\
\hline 1. & $\begin{array}{l}\text { Disiplin adalah sikap mental yang } \\
\text { tercermin dalam perbuatan atau } \\
\text { tingkah laku seseorang, kelompok } \\
\text { masyarakt berupa ketaatan } \\
\text { (obedience) terhadap peraturan, } \\
\text { norma yang berlaku dalam } \\
\text { masyarakat. } \\
\text { (Siagian } 2006: 145 \text { ) }\end{array}$ & $\begin{array}{c}\text { Variabel } \\
\text { bebas }\end{array}$ & $\begin{array}{l}\text { 1) Ketepatan waktu } \\
\text { 2) Menggunakan peralatan } \\
\text { instansi dengan baik } \\
\text { 3) Tanggung jawab yang } \\
\text { tinggi } \\
\text { 4) Ketaatan terhadap aturan } \\
\text { instansi } \\
\text { Rivai (2009:143) }\end{array}$ & $\begin{array}{c}\text { Skala } \\
\text { Ordinal }\end{array}$ \\
\hline 2. & $\begin{array}{l}\text { Kepuasan kerja adalah seperangkat } \\
\text { perilaku kerja positif yang berakar } \\
\text { pada kesadaran yang kental, } \\
\text { keyakinan yang fundamental, disertai } \\
\text { komitmen yang total pada paradigma } \\
\text { kerja yang integral. } \\
\text { Milkovich (2008:141) }\end{array}$ & $\begin{array}{c}\text { Variabel } \\
\text { bebas }\end{array}$ & $\begin{array}{l}\text { 1) Bersyukur } \\
\text { 2) Tanggungjawab } \\
\text { 3) Integritas } \\
\text { 4) Kompensasi } \\
\text { 5) Ruang kerja } \\
\text { Milkovich (2008:147) }\end{array}$ & $\begin{array}{l}\text { Skala } \\
\text { Ordinal }\end{array}$ \\
\hline 3. & $\begin{array}{l}\text { Motivasi adalah pemberian daya } \\
\text { penggerak, yang menciptakan } \\
\text { kegairahan kerja seseorang, agar } \\
\text { mereka mau bekerja sama, bekerja } \\
\text { efektif dan terintegrasi dengan segala } \\
\text { daya upayanya untuk mencapai } \\
\text { kepuasan. } \\
\text { Hasibuan (2008:65) }\end{array}$ & $\begin{array}{c}\text { Variabel } \\
\text { terikat }\end{array}$ & $\begin{array}{l}\text { 1) Usaha meningkatkan } \\
\text { kinerja } \\
\text { 2) Penghargaan } \\
\text { 3) Kebanggaan } \\
\text { 4) Semangat dalam } \\
\text { melaksanakan program. } \\
\text { 5) Disukai. } \\
\text { Hasibuan (2008:77) }\end{array}$ & $\begin{array}{c}\text { Skala } \\
\text { Ordinal }\end{array}$ \\
\hline 5. & $\begin{array}{l}\text { Kinerja adalah perilaku nyata yang } \\
\text { ditampilkan setiap pegawai sebagai } \\
\text { prestasi kerja yang dihasilkan oleh } \\
\text { pegawai tersebut sesuai dengan } \\
\text { peranannya dalam organisasi } \\
\text { Rivai }(2009: 87)\end{array}$ & $\begin{array}{c}\text { Variabel } \\
\text { terikat }\end{array}$ & $\begin{array}{l}\text { 1) Kuantitas } \\
\text { 2) Kualitas } \\
\text { 3) Konsistensi } \\
\text { Rivai (2009:97) }\end{array}$ & $\begin{array}{l}\text { Skala } \\
\text { Ordinal }\end{array}$ \\
\hline
\end{tabular}

Setelah perhitungan di atas, penetapan jumlah sampel dalam penelitian ini menggunakan metode stratified random sampling yaitu penarikan sampel berdasarkan pada strata populasi pada setiap bagian, sehingga sampel dalam penelitian ini berjumlah 88 orang pegawai, dengan rincian sebagai berikut : dapat dihitung jumlah sampel dalam penelitian ini sebagai berikut :

$$
\begin{aligned}
& \mathrm{n}=\frac{113}{1+113(0,05)^{2}} \\
& \mathrm{n}=\frac{113}{1.28} \\
& \mathrm{n}=88.28=88 \text {. }
\end{aligned}
$$
. 


\subsection{Uji Kualitas Data \\ 2.4.1 Uji Validitas}

Suliyanto (2011:133), uji validitas digunakan untuk mengukur sah atau valid tidaknya suatu kuesioner. Suatu kuesioner dikatakan valid jika pertanyaan pada kuesioner mampu untuk mengungkapkan sesuatu yang akan diukur oleh kuesioner tersebut. Metode yang digunakan untuk menguji validitas adalah melakukan korelasi antar skor butir pertanyaan dengan total skor konstruk atau variabel. Uji signifikansi dilakukan dengan membandingkan $r_{\text {hitung }}$ dengan $r_{\text {tabel }}$ maka indikator dinyatakan valid dan sebaliknya jika $r_{\text {tabel }}$ lebih kecil dari pada $r_{\text {hitung }}$ maka indikator dinyatakan tidak valid.

\subsubsection{Uji Reliabilitas}

Suliyanto (2011:136), uji reliabilitas sebenarnya adalah alat untuk mengukur suatu kuesioner yang merupakan indikator dari variabel atau konstruk. Suatu kuesioner dikatakan reliabel atau handal jika jawaban seseorang terhadap pernyataan adalah konsisten atau stabil dari waktu ke waktu. Pengukuran reliabilitas dapat dilakukan dengan dua cara yaitu :

a. Repeated Measure arau pengukuran ulang

Disini seseorang akan disodori pertanyaan yang sama pada waktu yang berbeda, dan kemudian dilihat apakah ia tetap konsisten dengan jawabannya.

b. One Shot atau pengukuran sekali saja

Disini pengukurannya hanya sekali saja dan kemudian hasilnya dibandingkan dengan pertanyaan lain atau mengukur korelasi antar jawaban pertanyaan. Program AMOS memberikan fasilitas untuk mengukur reliabilitas dengan uji statistik Cronbach Alpha. Suatu konstruk atau variabel dikatakan reliabel jika memberikan nilai Cronbach Alpha > 0,60.

\subsection{Uji Asumsi}

Untuk menjamin kesempurnaan pengunaan alat analisis statistika inferensial, secara teoritik dibutuhkan beberapa asumsi yang harus dipenuhi, setidak-tidaknya ada tiga asumsi yang harus dipenuhi, yaitu data yang dianalisis berdistribusi normal, tidak ada gejala mutikolinearitas dari seluruh data dari variabel eksogen dan tidak ada gejala heteroskedastisitas dari data yang dianalisis.

\subsubsection{Uji Normalitas Data}

Beberapa ciri dari sekelompok data yang mempunyai distribusi normal adalah bahwa dalam kelompok mempunyai satu harga ratarata $=0$ dengan standar deviasi $=1$. Selain itu sekelompok data dikatakan berdistribusi normal jika mempunyai harga rata-rata (mean), median dan modus yang sama besarnya. Teknik pengujian terhadap normalitas distribusi data dapat dilakukan dengan mengunakan berbagai pendekatan, diantaranya dengan scatter plot, dengan nilai $\mathrm{Z}$ Kolmogorov Smirnov atau dengan pendekatan Shapiro-Wilk. Deteksi normalitas distribusi data dengan scatter plot dapat dilihat dari penyebaran titik koordinat data. Data dinyatakan berdistribusi normal jika data tersebar di sekitar garis diagonalnya. Sedang penggunaan pendekatan nilai $\mathrm{Z}$ Kolmogorov Smirnov atau Shapiro-Wilk, bahwa suatu data dinyatakan berdistribusi normal jika harga taraf signifikansi yang dihasilkan dari pengujian lebih besar dari 0.05. Sebaliknya, jika taraf signifikansi lebih kecil dari 0.05 maka disimpulkan data tidak berdistribusi normal.

\section{Uji Non Multicolinearity}

Multikolinearitas adalah terjadinya hubungan yang signifikan (nyata) antara variabel bebas yang satu dengan variabel bebas yang lainnya, dan hal seperti itu dalam penggunaan SEM tidak diperbolehkan. Dengan kata lain bahwa secara individu tidak boleh terjadi pengaruh atau hubungan antar variabel bebas. Alat analisis yang dapat digunakan untuk mendeteksi ada tidaknya gejala multikoliaritas adalah dengan menggunakan harga dari Varians Inflation Factor (VIF). Jika dalam perhitungan dihasilkan harga VIF kurang 10, maka disimpulkan bahwa tidak ada gejala multikoliniaritas antar variabel bebas.

2. Uji Non Heteroscedasticity

Heteroskedastisitas adalah gejala munculnya ketidaksamaan harga varians dari residual pada pengamatan yang satu ke pengamatan yang lain. Asumsi yang diperlukan adalah tidak adanya gejala heteroskedastisitas. Deteksi terhadap ada tidaknya gejala heteroskedastisitas dapat dilakukan dengan menggunakan Uji Glejser. Uji Glejser adalah teknik pengujian dengan cara meregresikan data dari setiap variabel bebas dengan harga absolut residualnya. Hipotesis pengujiannya adalah :

Ho : Tidak terjadi heteroskedastisitas

$\mathrm{H}_{1}$ : Terjadi heteroskedastisitas 
Jika dari perhitungan dihasilkan harga taraf signifikansi > 0.05 maka Ho diterima, artinya data yang dianalisis tidak mempunyai gejala heteroskedastisitas.

\subsection{Pengembangan Diagram Jalur}

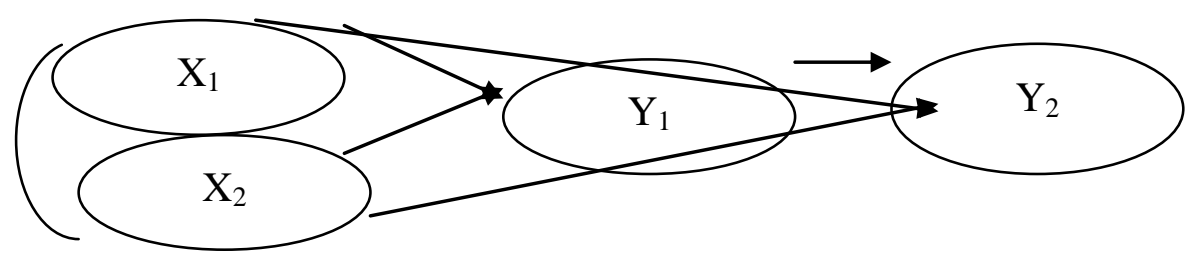

Gambar 1. Diagram jalur SEM

Dari gambar konseptual model penelitian tersebut, dapat disusun model strukturnya (structural model) sebagai berikut :

$$
\begin{array}{ll}
\mathrm{Y}_{1} & : \mathrm{b}_{1} \mathrm{X}_{1}+\mathrm{b}_{2} \mathrm{X}_{2} \\
\mathrm{Y}_{2} & : \mathrm{b}_{1} \mathrm{X}_{1}+\mathrm{b}_{2} \mathrm{X}_{2}+\mathrm{b}_{3} \mathrm{Y}_{1}
\end{array}
$$

\subsection{Uji Kecocokan}

Uji kecocokan ini dimaksudkan untuk menguji tingkat kecocokan (fitness) antara data empirik dengan model teoritiknya, validitas dan reliabilitas model pengukuran (measurement model) serta signifikansi koefisien-koefisien dalam model strukturalnya (structural model). Kecocokan untuk keseluruhan model (overal model fit) dapat digunakan beberapa alat evaluasi untuk Goodness of Fit (GOF) yang lazim digunakan dalam analisis SEM.

\subsection{Modifikasi Model dan Interpretasi Hasil Analisis}

Pada umumnya model dasar yang diuji seringkali tidak dapat menghasilkan angka yang goodness, oleh karena itu diperlukan modifikasi sesuai dengan petunjuk yang ada dalam modified indicates. Dengan melakukan berbagai modifikasi tersebut, diharapkan model dapat memberikan hasil yang baik, yaitu yang memenuhi kriteria sebagai model yang cocok. Dengan melakukan modifikasi tersebut, model yang diestimasi akan menghasilkan nilai residual kovarians yang kecil, bahkan mendekati nol. Sebagai tahap akhir dari SEM adalah memberikan penjelasan atau interpretasi
Sesuai dengan kerangka berpikir yang telah dipaparkan sebelumnya, dan juga sesuai dengan kerangka konseptual untuk konfirmatori setiap variabel, maka secara keseluruhan diagram jalur yang menunjukkan adanya hubungan dari satu variabel ke variabel yang lain dapat dilihat pada Gambar 3.1 berikut ini. hasil dari analisis, agar data yang menjelaskan adanya pengaruh antar variabel menjadi bermakna dan mempunyai implikasi manajerial yang jelas.

\subsection{Pengujian Hipotesis}

Pengujian terhadap hipotesis yang diajukan dalam penelitian ini dilakukan dengan menganalisis nilai Critical Ratio (CR) dan nilai Probability (P) dari hasil pengolahan data yang diperoleh, kemudian dibandingkan dengan batasan statistik yang disyaratkan, yaitu $\geq 1.96$ untuk nilai $\mathrm{CR}$ dan $\leq 0.05$ untuk nilai $\mathrm{P}$. Apabila hasil pengolahan data menunjukkan nilai yang memenuhi syarat tersebut, maka hipotesis penelitian yang diajukan dapat diterima. Pembahasan pada pengujian hipotesis dilakukan secara bertahap sesuai dengan urutan hipotesis yang diajukan, dengan ketentuan hipotesis :

Terima $\mathrm{H}_{0}$ jika koefisien $\mathrm{CR}\left(\mathrm{t}_{\text {hitung }}\right)<$ 1,96 atau koefisien $\mathrm{P}>0.05$ atau;

Terima $\mathrm{H}_{\mathrm{a}}$ jika koefisien CR $\left(\mathrm{t}_{\text {hitung }}\right) \geq$ 1,96 atau koefisien $\mathrm{P} \leq 0.05$.

\section{Hasil dan Pembahasan \\ 3.1. Uji Validitas}

Uji validitas adalah uji statistik yang digunakan untuk menentukan seberapa valid suatu item pernyataan dalam mengukur variabel yang diteliti. Berikut ini hasil uji validitas dari keempat variabel yang diteliti.

Tabel 2

Out put uji vaiditas

\begin{tabular}{|c|c|c|c|c|}
\hline Variabel & Angket & $\mathbf{r}>\mathbf{0 . 3}$ & Sig < 0.05 & Keterangan \\
\hline \multirow{2}{*}{$\begin{array}{c}\text { Disiplin } \\
\left(\mathrm{X}_{1}\right)\end{array}$} & $\mathrm{X}_{1.1}$ & 0.878 & 0.000 & Valid \\
\cline { 2 - 5 } & $\mathrm{X}_{1.2}$ & 0.607 & 0.000 & Valid \\
\cline { 2 - 5 } & $\mathrm{X}_{1.3}$ & 0.625 & 0.000 & Valid \\
\hline
\end{tabular}




\begin{tabular}{|c|c|c|c|c|}
\hline Variabel & Angket & $\mathbf{r}>\mathbf{0 . 3}$ & Sig < 0.05 & Keterangan \\
\hline \multirow{4}{*}{$\begin{array}{c}\text { Kepuasan kerja } \\
\left(\mathrm{X}_{2}\right)\end{array}$} & $\mathrm{X}_{1.4}$ & 0.549 & 0.000 & Valid \\
\cline { 2 - 5 } & $\mathrm{X}_{2.1}$ & 0.781 & 0.000 & Valid \\
\cline { 2 - 5 } & $\mathrm{X}_{2.2}$ & 0.903 & 0.000 & Valid \\
\cline { 2 - 5 } & $\mathrm{X}_{2.3}$ & 0.574 & 0.000 & Valid \\
\cline { 2 - 5 } & $\mathrm{X}_{2.4}$ & 0.714 & 0.000 & Valid \\
\cline { 2 - 5 } & $\mathrm{X}_{2.5}$ & 0.724 & 0.000 & Valid \\
\hline \multirow{4}{*}{$\begin{array}{c}\text { Motivasi kerja } \\
\left(\mathrm{Y}_{1}\right)\end{array}$} & $\mathrm{Y}_{1.1}$ & 0.634 & 0.000 & Valid \\
\cline { 2 - 5 } & $\mathrm{Y}_{1.2}$ & 0.522 & 0.000 & Valid \\
\cline { 2 - 5 } & $\mathrm{Y}_{1.3}$ & 0.548 & 0.000 & Valid \\
\cline { 2 - 5 } & $\mathrm{Y}_{1.4}$ & 0.588 & 0.000 & Valid \\
\cline { 2 - 5 } & $\mathrm{Y}_{1.5}$ & 0.629 & 0.000 & Valid \\
\hline \multirow{4}{*}{ Kinerja } & $\mathrm{Y}_{2.1}$ & 0.907 & 0.000 & Valid \\
\cline { 2 - 5 }$\left(\mathrm{Y}_{2}\right)$ & $\mathrm{Y}_{2.2}$ & 0.765 & 0.000 & Valid \\
\cline { 2 - 5 } & $\mathrm{Y}_{2.3}$ & 0.705 & 0.000 & Valid \\
\hline
\end{tabular}

Sumber : Hasil Pengolahan Data, 2019

Dari Tabel 2, di atas dapat dijelaskan bahwa nilai signifikansi butir-butir pernyataan untuk variabel keseluruhannya dinyatakan valid, karena nilai korelasinya lebih besar dari 0.3 dan nilai signifikansinya di bawah 0.05 .

\subsection{Uji Reliabilitas}

Uji reliabilitas adalah uji statistik yang digunakan untuk menentukan reliabilitas serangkaian item pernyataan dalam kehandalannya mengukur suatu variabel. Berikut ini hasil uji reliabilitas dari keempat variabel yang diteliti.

\section{Tabel 3}

Uji Reliabilitas

\begin{tabular}{|l|c|c|c|}
\hline \multicolumn{1}{|c|}{ Variabel } & $\begin{array}{c}\text { Nilai Alpha } \\
\text { Cronbach's }\end{array}$ & Reliabel/Tidak Reliabel & Keterangan \\
\hline Disiplin $\left(\mathrm{X}_{1}\right)$ & 0.496 & Reliabel (Tinggi) & Dipakai \\
\hline Kepuasan Kerja $\left(\mathrm{X}_{2}\right)$ & 0.792 & Reliabel (Cukup) & Dipakai \\
\hline Motivasi Kerja $\left(\mathrm{X}_{3}\right)$ & 0.498 & Reliabel (Tinggi) & Dipakai \\
\hline Kinerja $(Y)$ & 0.701 & Reliabel (Cukup) & Dipakai \\
\hline
\end{tabular}

Sumber : Hasil Pengolahan Data, 2019

Dari Tabel 3, diatas, diketahui nilai $r_{\text {tabel }}$ untuk uji dua sisi pada tingkat signifikan 5\% $(\alpha=$ 0,05 ), dengan jumlah sampel $\mathrm{N}=88$., maka derajat bebasnya adalah $\mathrm{N}-2=88-2=86$, dan diketahui nilai $\mathrm{r}_{\text {tabel }}=0.210$. Dari hasil pengolahan data penelitian diperoleh nilai $r_{\text {hitung }}$ pada kolom cronbach's alpha if item deleted semua lebih besar dari nilai $r_{\text {tabel }}$, maka seluruh butir pernyataan untuk variabel disiplin dinyatakan reliable.

\subsection{Analisis Data Penelitian}

Analisis data yang digunakan dalam penelitian ini adalah Structural Equation Model (SEM). Namun demikian beberapa tahapan analisis akan dilakukan untuk membentuk satu model yang terbaik. Input data yang digunakan dalam penelitian ini adalah matrik varians/kovarians. Matriks kovarian dinilai memiliki keuntungan dalam memberikan perbandingan yang valid antar populasi atau sampel yang berbeda, yang kadang tidak memungkinkan jika menggunakan model matriks korelasi. Model estimasi yang digunakan adalah maximum likelihood estimation karena jumlah data yang berada pada kisaran 100 - 200 buah. Sebelum pada pengujian model penuh, terlebih dahulu akan dilakukan pengujian secara bertahap yakni estimasi measurement model dengan teknik confirmatory factor analysis.

\subsection{Analisis Faktor Konfirmatori (Confirmatory Factor Analysis)}

Analisis faktor konfirmatori ini merupakan tahap pengukuran terhadap dimensi-dimensi yang membentuk variabel laten dalam model penelitian. Variabel-variabel atau konstruk laten yang digunakan pada model penelitian ini terdiri dari 4 variabel. Tujuan dari analisis 
faktor konfirmatori adalah untuk menguji validitas dari dimensi-dimensi pembentuk masing-masing variabel laten. Confirmatory factor analysis akan dilakukan terhadap setiap variabel laten maupun untuk konstruk variabel eksogen dan endogen.

\subsubsection{Confirmatory Factor Analysis Masing- masing Variabel Laten.}

Hasil confirmatory factor analysis adalah pengukuran terhadap dimensi-dimensi yang membentuk variabel laten dalam model penelitian. Hasilnya diringkas sebagai berikut.

Tabel. 4

Confirmatory Factor Analysis Variabel Latent

\begin{tabular}{|c|c|c|}
\hline Goodness of fit measurement & Dimensi & Loading factor \\
\hline \multicolumn{3}{|l|}{ Disiplin } \\
\hline \multirow[t]{4}{*}{ Chi square $=3,568$} & $\mathrm{X}_{1}$ & 0.812 \\
\hline & $X_{2}$ & 0.769 \\
\hline & $\mathrm{X}_{3}$ & 0.873 \\
\hline & $\mathrm{X}_{4}$ & 0.677 \\
\hline \multicolumn{3}{|l|}{ Kepuasan kerja } \\
\hline \multirow[t]{5}{*}{ Chi square $=5,459$} & $\mathrm{X}_{5}$ & 0.889 \\
\hline & $\mathrm{X}_{6}$ & 0.833 \\
\hline & $\mathrm{X}_{7}$ & 0.758 \\
\hline & $\mathrm{X}_{8}$ & 0.897 \\
\hline & $\mathrm{X}_{9}$ & 0.838 \\
\hline \multicolumn{3}{|l|}{ Motivasi kerja } \\
\hline \multirow[t]{5}{*}{ Chi square $=10,222$} & $X_{10}$ & 0.805 \\
\hline & $\mathrm{X}_{11}$ & 0.822 \\
\hline & $\mathrm{X}_{12}$ & 0.863 \\
\hline & $\mathrm{X}_{13}$ & 0.758 \\
\hline & $\mathrm{X}_{14}$ & 0.835 \\
\hline \multicolumn{3}{|l|}{ Kinerja } \\
\hline \multirow{3}{*}{$\begin{array}{l}\text { Chi square }=0,00 \\
\text { Prob }=\end{array}$} & $X_{15}$ & 0.832 \\
\hline & $\mathrm{X}_{16}$ & 0.726 \\
\hline & $X_{17}$ & 0.757 \\
\hline
\end{tabular}

Sumber : Data primer diolah, 2019

Hasil analisis pengolahan data terlihat bahwa semua konstruk yang digunakan untuk membentuk sebuah model penelitian, pada proses analisis factor konfirmatori telah memenuhi kriteria goodness of fit yang telah ditetapkan. Nilai probability pada analisis ini menunjukkan nilai diatas batas signifikansi yaitu 0.05 .

Dari hasil pengolahan data di atas, juga terlihat bahwa setiap indikator atau dimensi pembentuk masing-masing variable laten menunjukkan hasil baik, yaitu dengan nilai loading factor yang tinggi dimana masing- masing indikator lebih besar dari 0,5. Dengan hasil ini, maka dapat dikatakan bahwa indikator-indikator pembentuk variabel laten konstruk-kontruk variable laten tersebut sudah menunjukkan hasil yang baik.

\subsubsection{Analisis Faktor Konfirmatori Konstruk Eksogen}

Variabel-variabel laten atau konstruk eksogen terdiri dari 2 variabel laten dan terdiri dari 9 dimensi, hasil uji kelayakan model confirmatory factor analysis konstruk eksogen tersebut adalah sebagai berikut : 
Tabel 5

Confirmatory Factor Analysis Konstruk Eksogen

\begin{tabular}{|l|c|c|c|}
\hline $\begin{array}{c}\text { Goodness of Fit } \\
\text { Indeks }\end{array}$ & Cut-off Value & $\begin{array}{r}\text { Hasil } \\
\text { Analisis }\end{array}$ & $\begin{array}{c}\text { Evaluasi } \\
\text { Model }\end{array}$ \\
\hline Chi-Square (df =26) & $\leq 38.885$ & 37.418 & Baik \\
\hline Probability & $\geq 0.05$ & 0.069 & Baik \\
\hline RMSEA & $\leq 0.08$ & 0.067 & Baik \\
\hline GFI & $\geq 0.90$ & 0.918 & Baik \\
\hline AGFI & $\geq 0.90$ & 0.858 & Marginal \\
\hline TLI & $\geq 0.95$ & 0.975 & Baik \\
\hline CFI & $\geq 0.95$ & 0.982 & Baik \\
\hline
\end{tabular}

Sumber : Hasil pengolahan data, 2019

Hasil analisis pengolahan data terlihat bahwa semua konstruk yang digunakan untuk membentuk sebuah model penelitian, pada proses analisis faktor konfirmatori telah memenuhi kriteria goodness of fit yang telah ditetapkan. Nilai probability pada analisis ini menunjukkan nilai diatas batas signifikansi yaitu sebesar 0.069 ( $\mathrm{p}>0.05)$, nilai ini menunjukkan tidak adanya perbedaan antara matriks kovarian sample dengan matriks kovarian populasi yang diestimasi. Hasil pengujian terhadap nilai-nilai muatan faktor (loading faktor) untuk masing-masing indikator diperoleh sebagai berikut.

Tabel 6

Confirmatory Factor Analysis Konstruk Eksogen

\begin{tabular}{|r|l|l|r|r|r|r|}
\hline \multicolumn{2}{|c|}{} & \multicolumn{2}{r|}{ Estimate } & S.E. & C.R. & P \\
\hline X5 & $<---$ & Kepuasan kerja & 1.000 & & & \\
\hline X6 & $<---$ & Kepuasan kerja & .951 & .085 & 11.125 & $* * *$ \\
\hline X7 & $<---$ & Kepuasan kerja & .745 & .077 & 9.677 & $* * *$ \\
\hline X8 & $<---$ & Kepuasan kerja & .949 & .075 & 12.722 & $* * *$ \\
\hline X9 & $<--$ & Kepuasan kerja & .816 & .072 & 11.379 & $* * *$ \\
\hline X1 & $<--$ & Disiplin & 1.000 & & & \\
\hline X2 & $<---$ & Disiplin & .877 & .103 & 8.545 & $* * *$ \\
\hline X3 & $<---$ & Disiplin & 1.101 & .116 & 9.508 & $* * *$ \\
\hline X4 & $<---$ & Disiplin & .809 & .121 & 6.659 & $* * *$ \\
\hline
\end{tabular}

Sumber : Hasil pengolahan data, 2019

Dari pengolahan data diatas dapat juga terlihat, bahwa setiap indikator atau dimensi pembentuk masing-masing variabel laten menunjukkan hasil yang baik, yaitu nilai CR diatas 1,96. Semua nilai probabilitas untuk masing-masing indikator lebih kecil dari 0,05. Dengan hasil ini, maka dapat dikatakan bahwa indikatorindikator pembentuk variabel laten konstruk telah menunjukkan sebagai indikator yang kuat dalam pengukuran varibel laten. Selanjutnya berdasarkan analisis faktor konformatori ini, maka model penelitian ini dapat digunakan untuk analisis selanjutnya tanpa modifikasi atau penyesuaian-penyesuaian

\subsubsection{Analisis Faktor Konfirmatori Konstruk Endogen}

Variabel-variabel laten atau konstruk endogen terdiri dari 2 variabel laten dengan 8 dimensi. Hasil pengolahan uji kelayakan model confirmatory factor analysis konstruk endogen tersebut adalah sebagai berikut :

Tabel 7

Confirmatory Factor Analysis Konstruk Endogen

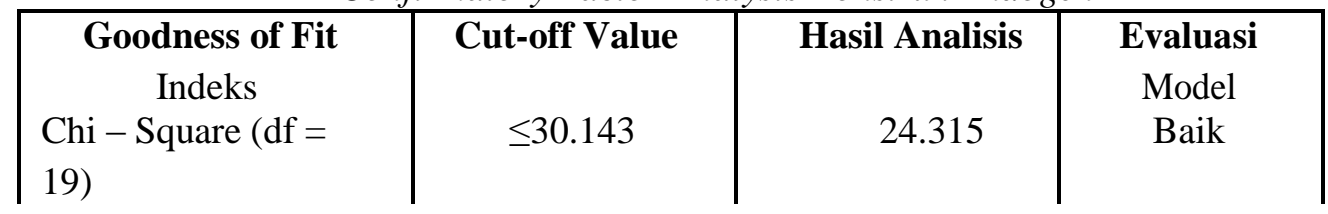




\begin{tabular}{|l|c|c|c|}
\hline \multicolumn{1}{|c|}{ Goodness of Fit } & Cut-off Value & Hasil Analisis & Evaluasi \\
Probability & $\geq 0.05$ & 0.184 & Baik \\
RMSEA & $\leq 0.08$ & 0.053 & Baik \\
GFI & $\geq 0.90$ & 0.945 & Baik \\
AGFI & $\geq 0.90$ & 0.896 & Marginal \\
TLI & $\geq 0.95$ & 0.984 & Baik \\
CFI & $\geq 0.95$ & 0.989 & Baik
\end{tabular}

Hasil analisis pengolahan data terlihat bahwa semua konstruk yang digunakan untuk membentuk sebuah model penelitian, pada proses analisis faktor konfirmatori telah memenuhi kriteria goodness of fit yang telah ditetapkan. Nilai probability pada analisis ini

menunjukkan nilai diatas batas signifikansi yaitu sebesar 0.184 atau diatas 0.05 , nilai ini menunjukkan tidak adanya perbedaan antara matriks kovarian sample dengan matriks kovarian populasi yang diestimasi.

Tabel 8

Standarisasi Regression Weights

Confirmatory Factor Analysis Konstruk Endogen

\begin{tabular}{|l|l|l|r|r|r|r|}
\hline \multicolumn{9}{|c|}{ Estimate } & \multicolumn{1}{c|}{ S.E. } & \multicolumn{1}{c|}{ C.R. } \\
\hline $\mathrm{X}_{12}$ & $<---$ & Motivasi_kerja & 1.000 & & & \\
\hline $\mathrm{X}_{11}$ & $<---$ & Motivasi_kerja & 1.008 & .099 & 10.203 & $* * *$ \\
\hline $\mathrm{X}_{10}$ & $<---$ & Motivasi_kerja & .990 & .102 & 9.755 & $* * *$ \\
\hline $\mathrm{X}_{15}$ & $<---$ & Kinerja_pegawai & 1.000 & & & \\
\hline $\mathrm{X}_{16}$ & $<---$ & Kinerja_pegawai & .869 & .127 & 6.849 & $* * *$ \\
\hline $\mathrm{X}_{17}$ & $<---$ & Kinerja_pegawai & 1.094 & .142 & 7.688 & $* * *$ \\
\hline $\mathrm{X}_{13}$ & $<---$ & Motivasi_kerja & .892 & .102 & 8.783 & $* * *$ \\
\hline $\mathrm{X}_{14}$ & $<--$ & Motivasi_kerja & .996 & .096 & 10.411 & $* * *$ \\
\hline
\end{tabular}

Dari pengolahan data diatas dapat juga terlihat, bahwa setiap indikator atau dimensi pembentuk masing-masing variabel laten menunjukkan hasil yang baik, yaitu nilai CR diatas 1,96. Semua nilai probabilitas untuk masing-masing indikator lebih kecil dari 0,05. Dengan hasil ini, maka dapat dikatakan bahwa indikatorindikator pembentuk variabel laten konstruk telah menunjukkan sebagai indikator yang kuat dalam pengukuran varibel laten. Selanjutnya, berdasarkan analisis faktor konfirmatori ini, maka model penelitian ini dapat digunakan untuk analisis selanjutnya tanpa modifikasi atau penyesuaian-penyesuaian

\subsubsection{Analisis Full Model-Structural Equation Model}

Analisis hasil pengolahan data pada tahap full model SEM dilakukan dengan melakukan uji kesesuaian dan uji statistik. Hasil pengolahan uji terhadap kelayakan model menunjukkan bahwa model ini sesuai dengan data atau fit terhadap data yang digunakan dalam penelitian adalah seperti telihat pada tabel berikut ini :

Tabel 9

Structural Equation Model (SEM)

\begin{tabular}{|l|c|c|c|}
\hline \multicolumn{1}{|c|}{ Goodness of Fit } & Cut-off Value & Hasil & Evaluasi Model \\
\hline Indeks & & Analisis & \\
\hline Chi - Square & $\leq 138.811$ & 120.528 & Baik \\
\hline Probability & $\geq 0.05$ & 0.297 & Baik \\
\hline RMSEA & $\leq 0.08$ & 0.026 & Baik \\
\hline GFI & $\geq 0.90$ & 0.876 & Marginal \\
\hline AGFI & $\geq 0.90$ & 0.833 & Marginal \\
\hline TLI & $\geq 0.95$ & 0.993 & Baik \\
\hline
\end{tabular}




\begin{tabular}{|l|c|c|c|}
\hline \multicolumn{1}{|c|}{ Goodness of Fit } & Cut-off Value & Hasil & Evaluasi Model \\
\hline CFI & $\geq 0.95$ & 0.994 & Baik \\
\hline Chi square / df & $\geq 2.00$ & 1.067 & Baik \\
\hline
\end{tabular}

Hasil analisis pengolahan data terlihat bahwa semua konstruk yang digunakan untuk membentuk sebuah model penelitian, pada proses analisis full model SEM telah memenuhi kriteria goodness of fit yang telah ditetapkan. Nilai probability pada analisis ini menunjukkan nilai diatas batas signifikansi yaitu sebesar 0.297 ( $p>0.05$ ). Nilai ini menunjukkan tidak adanya perbedaan antara matriks kovarian prediksi dengan matriks kovarian yang diestimasi. Ukuran goodness of fit lain juga menunjukkan pada kondisi yang baik meskipun GFI dan AGFI belum mencapai nilai 0,90. Untuk mendapatkan model yang baik, akan terlebih dahulu diuji masalah penyimpangan terhadap asumsi SEM.

\subsection{Analisis Asumsi SEM}

\subsubsection{Evaluasi Normalitas Data}

Asumsi normalitas data diuji dengan melihat nilai skewness dan kurtosis dari data yang digunakan. Apabila nilai CR pada skewness maupun kurtosis data berada pada rentang antara \pm 2.58 , maka data masih dapat dinyatakan berdistribusi pada tingkat signifikansi 0.01. Hasil pengujian normalitas data ditampilkan pada Tabel dibawah ini

Tabel 13

Assessment of Normality

\begin{tabular}{|c|r|r|r|r|r|r|}
\hline Variable & Min & max & skew & c.r. & kurtosis & c.r. \\
\hline X9 & 1.000 & 7.000 & -.476 & -1.943 & -.473 & -.965 \\
X8 & 1.000 & 7.000 & -.391 & -1.598 & -.664 & -1.354 \\
X7 & 1.000 & 7.000 & -.469 & -1.916 & -.619 & -1.264 \\
X6 & 1.000 & 7.000 & -.390 & -1.591 & -.644 & -1.927 \\
X5 & 1.000 & 7.000 & -.360 & -1.469 & -.449 & -1.937 \\
X14 & 1.000 & 7.000 & -.397 & -1.619 & -.499 & -1.018 \\
X13 & 1.000 & 7.000 & -.309 & -1.261 & -.689 & -1.407 \\
X12 & 1.000 & 7.000 & -.441 & -1.799 & -.198 & -.403 \\
X11 & 1.000 & 7.000 & -.307 & -1.254 & -.308 & -1.650 \\
X10 & 1.000 & 7.000 & -.468 & -1.909 & -.592 & -1.209 \\
X17 & 1.000 & 7.000 & -.541 & -2.209 & -.196 & -.400 \\
X16 & 1.000 & 7.000 & -.598 & -2.440 & .041 & .084 \\
X15 & 1.000 & 7.000 & -.508 & -2.073 & -.412 & -.841 \\
X4 & 1.000 & 7.000 & -.528 & -2.154 & .026 & .053 \\
X3 & 1.000 & 7.000 & -.341 & -1.391 & -.545 & -1.113 \\
X2 & 1.000 & 7.000 & -.444 & -1.813 & .169 & .344 \\
X1 & 1.000 & 7.000 & -.367 & -1.499 & -.667 & -1.362 \\
Multivariate & & & & & 12.669 & 2.469
\end{tabular}

Hasil pengujian normalitas data sebagaimana pada Tabel 4.12 menunjukkan bahwa tidak terdapat nilai C.R. untuk skewness dan kurtosis yang berada diluar rentang \pm 2.58 . Dengan demikian maka data penelitian yang digunakan telah memenuhi persyaratan normalitas data, atau dapat dikatakan bahwa data penelitian telah terdistribusi normal. Dengan demikian asumsi data yang normal dalam hal ini dapat terpenuhi.

\subsection{Evaluasi atas Outlier}

Evaluasi atas outlier univariat dan outlier multivariat disajikan pada bagian berikut ini :

\section{a. Univariate Outliers}

Pengujian ada tidaknya outlier univariate dilakukan dengan menganalisis nilai $\mathrm{Z}$ score 
dari data penelitian yang digunakan. Apabila terdapat nilai $\mathrm{Z}$ score berada pada rentang $\geq 3$, maka akan dikategorikan sebagai outlier. Hasil pengolahan data untuk pengujian ada tidaknya outlier ada pada Tabel berikut ini.

Tabel 14

Pengujian outlier univariate

\begin{tabular}{|l|c|c|c|c|c|}
\hline \multicolumn{7}{|c|}{ Descriptive Statistics } \\
\hline & $\mathrm{N}$ & Minimum & Maksimum & Mean & Std. Deviasi \\
\hline ZScore $\left(\mathrm{X}_{1}\right)$ & 88 & -2.50728 & 1.59182 & .000000 & 1.000000 \\
\hline ZScore $\left(\mathrm{X}_{2}\right)$ & 88 & -2.81240 & 1.81073 & .000000 & 1.000000 \\
\hline ZScore $\left(\mathrm{X}_{3}\right)$ & 88 & -2.59107 & 1.45748 & .000000 & 1.000000 \\
\hline ZScore $\left(\mathrm{X}_{4}\right)$ & 88 & -2.35323 & 1.68088 & .000000 & 1.000000 \\
\hline ZScore $\left(\mathrm{X}_{5}\right)$ & 88 & -2.23481 & 1.33138 & .000000 & 1.000000 \\
\hline ZScore $\left(\mathrm{X}_{6}\right)$ & 88 & -2.25294 & 1.27647 & .000000 & 1.000000 \\
\hline ZScore $\left(\mathrm{X}_{7}\right)$ & 88 & -2.45364 & 1.71685 & .000000 & 1.000000 \\
\hline ZScore $\left(\mathrm{X}_{8}\right)$ & 88 & -2.30266 & 1.48253 & .000000 & 1.000000 \\
\hline ZScore $\left(\mathrm{X}_{9}\right)$ & 88 & -2.52069 & 1.64574 & .000000 & 1.000000 \\
\hline ZScore $\left(\mathrm{X}_{10}\right)$ & 88 & -2.50022 & 1.32665 & .000000 & 1.000000 \\
\hline ZScore $\left(\mathrm{X}_{11}\right)$ & 88 & -2.40587 & 1.45381 & .000000 & 1.000000 \\
\hline ZScore $\left(\mathrm{X}_{12}\right)$ & 88 & -2.62141 & 1.38074 & .000000 & 1.000000 \\
\hline ZScore $\left(\mathrm{X}_{13}\right)$ & 88 & -2.50517 & 1.46080 & .000000 & 1.000000 \\
\hline ZScore $\left(\mathrm{X}_{14}\right)$ & 88 & -2.55454 & 1.41625 & .000000 & 1.000000 \\
\hline ZScore $\left(\mathrm{X}_{15}\right)$ & 88 & -2.41011 & 1.48764 & .000000 & 1.000000 \\
\hline ZScore $\left(\mathrm{X}_{16}\right)$ & 88 & -2.56036 & 1.54717 & .000000 & 1.000000 \\
\hline ZScore $\left(\mathrm{X}_{17}\right)$ & 88 & -2.65577 & 1.25937 & .000000 & 1.000000 \\
\hline
\end{tabular}

Sumber : Hasil pengolahan data, 2019

Sebaran data untuk setiap observed variable menunjukkan tidak adanya indikasi outlier. Hal ini ditunjukkan dengan nilai Zscore dari data penelitian yang nilainya berada pada rentang $\leq$ 3.00

\section{b. Multivariate Outliers}

Evaluasi terhadap multivariate outliers dilakukan dengan mengevaluasi nilai jarak Mahalonobis (Mahalonobis Distance) untuk tiap-tiap observasi (Hair, et al 1995 dalam Ferdinand, 2002:88). Hasil pengujian diperoleh sebagai berikut :

Tabel 15

Pengujian outlier multivariate

\begin{tabular}{|r|r|r|r|}
\hline Observation number & Mahalanobis d-squared & $\mathrm{p} 1$ & $\mathrm{p} 2$ \\
\hline 35 & 34.394 & .007 & .001 \\
\hline 61 & 32.781 & .012 & .001 \\
\hline 18 & 29.641 & .029 & .027 \\
\hline 26 & 29.553 & .030 & .010 \\
\hline 51 & 29.400 & .031 & .004 \\
\hline 75 & 28.452 & .040 & .007 \\
\hline 36 & 28.433 & .040 & .002 \\
\hline 16 & 26.737 & .062 & .021 \\
\hline
\end{tabular}

Sumber : Hasil pengolahan data, 2019

Tabel tersebut menunjukkan 8 buah sampel dengan nilai jarak mahalonobis terbesar (dsquare terbesar). Nilai-nilai tersebut jika dibandingkan dengan nilai chi-square pada derajad bebas sebesar 17 (jumlah dimensi) pada tingkat $\mathrm{p}<0.001$ adalah ${ }_{(17,0.001)}^{2}=40.790$. Dari hasil pengolahan data dapat diketahui bahwa jarak mahalanobis maksimal 34,394. Jadi dalam analisis ini tidak ditemukan adanya outlier secara multivariate, sehingga tidak diperlukan ekslusi terhadap data sampel.

\subsection{Evaluasi atas Multicollinearity dan singularity}

Pengujian data selanjutnya adalah untuk melihat apakah terdapat multikolinearitas dan 
singularitas dalam sebuah kombinasi variabel. Indikasi adanya multikolinearitas dan singularitas dapat diketahui melalui nilai determinan matriks kovarians yang benar-benar kecil, atau mendekati nol. Dari hasil pengolahan data nilai determinan matriks kovarians sample adalah :

\section{Determinant of sample covariance matrix $=$} 1,255

Dari hasil pengolahan data tersebut dapat diketahui nilai determinan matriks kovarians sample berada jauh dari nol. Dengan demikian dapat dikatakan bahwa data penelitian yang digunakan tidak terdapat multikolinearitas dan singularitas,

\subsection{Evaluasi Terhadap Nilai Residual}

Interpretasi dan modifikasi dimaksudkan untuk melihat apakah model yang dikembangkan dalam penelitian ini, perlu dimodifikasi atau dirubah sehingga mendapatkan model yang lebih baik lagi. Sebuah model penelitian dikatakan baik jika memiliki nilai Standardized Residual Covarian yang didalam standar yang ditetapkan $(\leq \pm$ 2,58). Hasil Standardized Residual Covarian model penelitian ini ditampilkan pada lampiran.

Hasil analisis pada penelitian ini tidak menunjukkan adanya nilai standardized residual covariance yang melebihi $\pm 2,58$. Nilai standardized residual covariance terbesar adalah -1,745 (pada kolom X6 dan baris X4) yang lebih kecil dari 2,58. Dengan melihat pada hasil tersebut maka tidak perlu dilakukan modifikasi model penelitian ini.

\subsection{Uji Reliability dan Variance Extract}

Uji reliabilitas menunjukkan sejauh mana suatu alat ukur yang dapat memberikan hasil yang relatif sama apabila dilakukan pengukuran kembali pada obyek yang sama. Nilai reliabilitas minimum dari dimensi pembentuk variabel laten yang dapat diterima adalah sebesar adalah 0.70 . Untuk mendapatkan nilai tingkat reliabilitas dimensi pembentuk variabel laten.

Hasil pengolahan data ditampilkan pada Tabel berikut ini.

Tabel 16

Reliability dan variance extract

\begin{tabular}{|l|c|c|}
\hline \multicolumn{1}{|c|}{ Variabel } & Reliability & Variance Extract \\
\hline Disiplin & 0.863 & 0.615 \\
\hline Kepuasan kerja & 0.926 & 0.715 \\
\hline Motivasi & 0.909 & 0.668 \\
\hline Kinerja Pegawai & 0.812 & 0.592 \\
\hline
\end{tabular}

Sumber : Hasil pengolahan data, 2019

Hasil pengujian menunjukkan semua nilai reliability berada di atas 0,7 . Hal ini berarti bahwa pengukuran model SEM ini sudah memenuhi syarat reliabilitas pengukur. Nilai variance extract juga berada di atas 0,5 . Hal ini berarti bahwa pengukuran model SEM ini sudah memenuhi syarat ekstraksi faktor yang baik

\subsection{Uji Hipotesis}

Hasil analisis SEM sebagai langkah pengujian hipotesis adalah sebagai berikut :

Tabel 17

Uji Hipotesis

\begin{tabular}{|l|r|l|r|r|r|r|}
\hline & & & Estimate & S.E. & C.R. & P \\
\hline Motivasi kerja & $<--$ & Disiplin & .221 & .107 & 2.064 & .039 \\
\hline Motivasi kerja & $<---$ & Kepuasan_Kerja & .710 & .156 & 4.540 & .000 \\
\hline Kinerja_Pegawai & $<---$ & Kepuasan_Kerja & .436 & .209 & 2.086 & .037 \\
\hline Kinerja_Pegawai & $<---$ & Motivasi kerja & .255 & .176 & 1.454 & .046 \\
\hline Kinerja_Pegawai & $<---$ & Disiplin & .189 & .112 & 1.692 & .041 \\
\hline
\end{tabular}




\subsubsection{Pengaruh Disiplin Terhadap Motivasi Kerja Pegawai Di Kantor Pelayanan Pajak Pratama Medan Petisah}

Parameter estimasi hubungan antara disiplin terhadap motivasi kerja pegawai diperoleh sebesar 0.221. Pengujian hubungan kedua variabel tersebut menunjukkan nilai $\mathrm{C} . \mathrm{R}=$ 2.064 dengan probabilitas $=0,039(\mathrm{p}<0,05)$. Jadi dapat disimpulkan bahwa disiplin berpengaruh positif terhadap motivasi kerja pegawai Kantor Pelayanan Pajak Pratama Medan Petisah, sehingga semakin tinggi disiplin yang dimiliki pegawai maka motivasi kerja pegawai akan semakin tinggi juga.

\subsubsection{Pengaruh Kepuasan Kerja Terhadap Motivasi Kerja Pegawai Di Kantor Pelayanan Pajak Pratama Medan Petisah}

Parameter estimasi hubungan antara kepuasan kerja terhadap motivasi kerja pegawai diperoleh sebesar 0.710. Pengujian hubungan kedua variabel tersebut menunjukkan nilai C.R $=4.540$ dengan probabilitas $=0,000(\mathrm{p}<0,05)$. Jadi dapat disimpulkan bahwa kepuasan kerja berpengaruh positif terhadap motivasi kerja pegawai Kantor Pelayanan Pajak Pratama Medan Petisah, sehingga semakin tinggi kepuasan kerja yang dimiliki pegawai maka motivasi kerja pegawai akan semakin tinggi juga.

\subsubsection{Pengaruh Disiplin Terhadap Kinerja Pegawai Di Kantor Pelayanan Pajak Pratama Medan Petisah}

Parameter estimasi hubungan antara disiplin terhadap kinerja pegawai diperoleh sebesar 0.189. Pengujian hubungan kedua variabel tersebut menunjukkan nilai C.R $=1.692$ dengan probabilitas $=0,041(\mathrm{p}<0,05)$. Jadi dapat disimpulkan bahwa disiplin berpengaruh positif terhadap kinerja pegawai Kantor Pelayanan Pajak Pratama Medan Petisah, sehingga semakin tinggi disiplin yang dimiliki pegawai maka kinerja pegawai akan semakin tinggi juga.

\subsubsection{Pengaruh Kepuasan Kerja Terhadap Kinerja Pegawai Di Kantor Pelayanan Pajak Pratama Medan Petisah}

Parameter estimasi hubungan antara kepuasan kerja terhadap kinerja pegawai diperoleh sebesar 0.436. Pengujian hubungan kedua variabel tersebut menunjukkan nilai C.R $=2.086$ dengan probabilitas $=0,037(\mathrm{p}<0,05)$. Jadi dapat disimpulkan bahwa kepuasan kerja berpengaruh positif terhadap kinerja pegawai Kantor Pelayanan Pajak Pratama Medan Petisah, sehingga semakin tinggi kepuasan kerja yang dimiliki pegawai maka kinerja pegawai akan semakin tinggi juga.

\subsubsection{Pengaruh Motivasi Kerja Terhadap Kinerja Pegawai Di Kantor Pelayanan Pajak Pratama Medan Petisah}

Parameter estimasi hubungan antara motivasi kerja terhadap kinerja pegawai diperoleh sebesar 0.255 . Pengujian hubungan kedua variabel tersebut menunjukkan nilai C.R $=1.454$ dengan probabilitas $=0,046(\mathrm{p}<0,05)$. Jadi dapat disimpulkan bahwa motivasi kerja berpengaruh positif terhadap kinerja pegawai Kantor Pelayanan Pajak Pratama Medan Petisah, sehingga semakin tinggi motivasi kerja yang dimiliki pegawai maka kinerja pegawai akan semakin tinggi juga.

\subsection{Analisis Pengaruh Variabel Eksogen Terhadap Variabel Endogen}

Analisis ini diperlukan untuk mengetahui besarnya pengaruh variabel eksogen terhadap variabel endogen secara menyeluruh. Analisis ini juga dilakukan untuk mengetahui pengaruh langsung maupun tidak langsung antara variabel eksogen terhadap variabel endogen. Besarnya pengaruh masing-masing variabel eksogen terhadap variabel endogen secara menyeluruh tampak pada tabel 18, kemudian pengaruh secara langsung tampak pada 5.28 dan pengaruh secara tidak langsung tampak pada tabel 20, sebagai berikut:

Tabel 18

Standardized Total Effects

\begin{tabular}{|l|r|r|rr|r|}
\hline \multirow{2}{*}{} & \multirow{2}{*}{ Disiplin } & \multicolumn{2}{c|}{ Kepuasan } & Motivasi & \multicolumn{2}{l|}{ Kinerja } \\
\cline { 3 - 6 } & & \multicolumn{1}{c|}{ Kerja } & Kerja & \multicolumn{1}{c|}{ Pegawai } \\
\hline Motivasi Kerja & .260 & .653 & .000 & .000 \\
\hline Kinerja Pegawai & .307 & .606 & .273 & .000 \\
\hline X9 & .842 & .000 & .000 & .000 \\
\hline X8 & .890 & .000 & .000 & .000 \\
\hline X7 & .772 & .000 & .000 & .000 \\
\hline
\end{tabular}




\begin{tabular}{|l|r|r|r|r|}
\hline $\mathrm{X} 6$ & .835 & .000 & .000 & .000 \\
\hline $\mathrm{X} 5$ & .884 & .000 & .000 & .000 \\
\hline $\mathrm{X} 14$ & .221 & .555 & .850 & .000 \\
\hline $\mathrm{X} 13$ & .197 & .496 & .760 & .000 \\
\hline $\mathrm{X} 12$ & .217 & .546 & .837 & .000 \\
\hline $\mathrm{X} 11$ & .215 & .540 & .828 & .000 \\
\hline $\mathrm{X} 10$ & .210 & .527 & .807 & .000 \\
\hline $\mathrm{X} 17$ & .254 & .501 & .225 & .826 \\
\hline $\mathrm{X} 16$ & .217 & .428 & .192 & .706 \\
\hline $\mathrm{X} 15$ & .237 & .467 & .210 & .771 \\
\hline $\mathrm{X} 4$ & .000 & .649 & .000 & .000 \\
\hline $\mathrm{X} 3$ & .000 & .877 & .000 & .000 \\
\hline $\mathrm{X} 2$ & .000 & .798 & .000 & .000 \\
\hline $\mathrm{X} 1$ & .000 & .796 & .000 & .000 \\
\hline Sumber $:$ Hasil pengolahan data, 2019 & & & \\
\hline
\end{tabular}

Dari tabel 18, menunjukkan pengaruh secara menyeluruh dari variabel disiplin terhadap kinerja pegawai sebesar 0.307, pengaruh variabel kepuasan kerja terhadap kinerja pegawai sebesar 0.606 , dan pengaruh motivasi kerja terhadap kinerja pegawai sebesar 0.273. Jadi, kesimpulan yang dapat ditarik adalah variabel kepuasan kerja memberikan pengaruh yang paling besar terhadap kinerja pegawai, sedangkan variabel motivasi kerja memberikan pengaruh yang kecil terhadap kinerja pegawai. Sebagai tambahan, pengaruh variabel disiplin terhadap motivasi kerja adalah sebesar 0.260 dan pengaruh variabel kepuasan kerja terhadap motivasi kerja adalah sebesar 0.653. Selanjutnya, pengaruh langsung variabel eksogen terhadap variabel endogen dapat dilihat pada tabel 5.28 berikut.

Tabel 19

Standardized Direct Effects

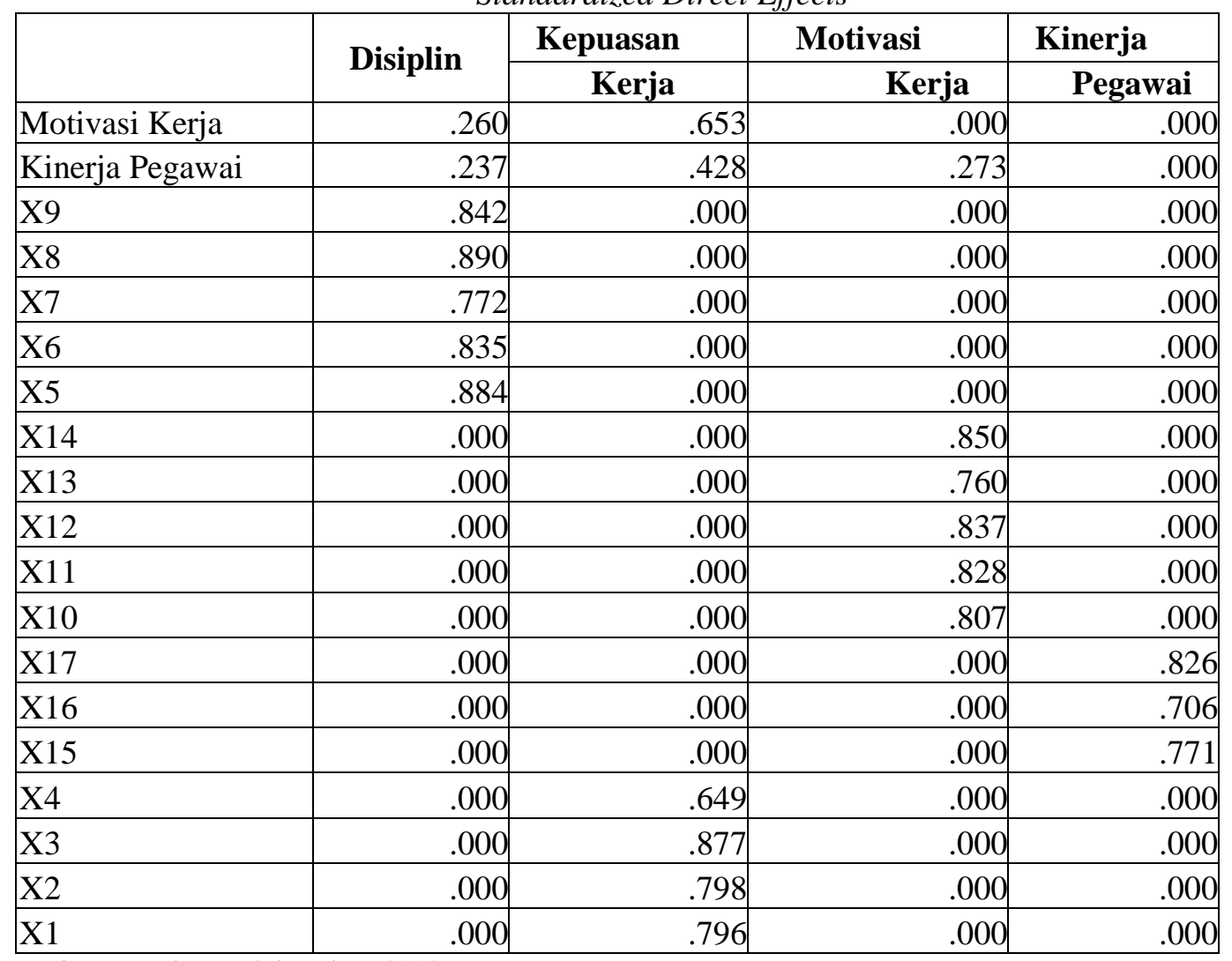

Sumber : Hasil pengolahan data, 2019 
Dari tabel 19, menunjukkan bahwa terdapat pengaruh langsung variabel disiplin terhadap kinerja pegawai dan variabel kepuasan kerja terhadap kinerja pegawai. Pengaruh variabel disiplin terhadap kinerja pegawai secara langsung adalah senilai 0.237. Pengaruh variabel kepuasan kerja terhadap kinerja pegawai secara langsung adalah senilai 0.428 .
Jadi, dapat diambil suatu kesimpulan bahwa variabel kepuasan kerja memberikan pengaruh secara langsung yang lebih besar terhadap kinerja pegawai apabila dibandingkan dengan pengaruh variabel disiplin. Selanjutnya, berikut ini adalah tabel 5.29 yang menunjukkan hubungan tidak langsung antara variabel eksogen dengan variabel endogennya

Tabel 20

Standardized Indirect Effects

\begin{tabular}{|c|c|c|c|c|}
\hline & Disiplin & $\begin{array}{c}\text { Kepuasan } \\
\text { Kerja }\end{array}$ & $\begin{array}{c}\text { Motivasi } \\
\text { Kerja }\end{array}$ & $\begin{array}{l}\text { Kinerja } \\
\text { Pegawai }\end{array}$ \\
\hline Motivasi Kerja & .000 & .000 & .000 & .000 \\
\hline Kinerja Pegawai & .071 & .178 & .000 & .000 \\
\hline $\mathrm{X} 9$ & .000 & .000 & .000 & .000 \\
\hline $\mathrm{X} 8$ & .000 & .000 & .000 & .000 \\
\hline $\mathrm{X7}$ & .000 & .000 & .000 & .000 \\
\hline $\mathrm{X} 6$ & .000 & .000 & .000 & .000 \\
\hline $\mathrm{X} 5$ & .000 & .000 & .000 & .000 \\
\hline $\mathrm{X} 14$ & .221 & .555 & .000 & .000 \\
\hline $\mathrm{X} 13$ & .197 & .496 & .000 & .000 \\
\hline $\mathrm{X} 12$ & .217 & .546 & .000 & .000 \\
\hline X11 & .215 & .540 & .000 & .000 \\
\hline $\mathrm{X} 10$ & .210 & .527 & .000 & .000 \\
\hline $\mathrm{X} 17$ & .254 & .501 & .225 & .000 \\
\hline $\mathrm{X} 16$ & .217 & .428 & .192 & .000 \\
\hline $\mathrm{X} 15$ & .237 & .467 & .210 & .000 \\
\hline $\mathrm{X} 4$ & .000 & .000 & .000 & .000 \\
\hline $\mathrm{X} 3$ & .000 & .000 & .000 & .000 \\
\hline $\mathrm{X} 2$ & .000 & .000 & .000 & .000 \\
\hline $\mathrm{X} 1$ & .000 & .000 & .000 & .00 \\
\hline
\end{tabular}

Sumber : Hasil pengolahan data, 2019

Dari tabel 20, diatas dapat dilihat bahwa pengaruh disiplin terhadap kinerja pegawai secara tidak langsung adalah sebesar 0.071. Sedangkan pengaruh kepuasan kerja terhadap kinerja pegawai secara tidak langsung adalah sebesar 0.178. Jadi, dapat ditarik kesimpulan bahwa variabel kepuasan kerja memberikan pengaruh yang lebih besar terhadap kinerja pegawai dibandingkan dengan variabel disiplin.

\section{Kesimpulan}

1. Pengujian hipotesis yang dilakukan menunjukkan bahwa ada pengaruh positif antara kepuasan kerja dengan kinerja pegawai dengan nilai Critical Ratio (C.R) 2.086 dengan $\mathrm{P}$ (Probability) sebesar 0,037 $(\mathrm{p}<0,05)$.
2. Pengujian hipotesis yang dilakukan menunjukkan bahwa ada pengaruh positif antara disiplin dengan kinerja pegawai dengan dari nilai Critical Ratio (C.R) sebesar 1.693 dengan P (Probability) sebesar 0,041 ( $<$ < $0,05)$.

3. Pengujian hipotesis yang dilakukan menunjukkan bahwa ada pengaruh positif antara kepuasan kerja dengan motivasi kerja dengan nilai Critical Ratio (C.R) sebesar 4.540 dengan $\mathrm{P}$ (Probability) sebesar 0,000 (p $<0,05)$.

4. Pengujian hipotesis yang dilakukan menunjukkan bahwa ada pengaruh positif antara disiplim dengan motivasi kerja dengan nilai Critical Ratio (C.R) sebesar 2.064 dengan P (Probability) sebesar 0,039 (p < $0,05)$. 
5. Pengujian hipotesis yang dilakukan menunjukkan bahwa ada pengaruh positif antara motivasi kerja dengan kinerja pegawai dengan nilai Critical Ratio (C.R) sebesar 1.454 dengan P (Probability) sebesar 0,046 ( $p<0,05)$, namun tidak signifikan pada $\alpha 5 \%$.

\section{DAFTAR PUSTAKA}

Ali, A.Y.S., Dahie, A.M., dan Ali, A.A. (2016). Teacher Motivation and School Performance, the Mediating Effect of Job Satisfaction: Survey from Secondary Schools in Mogadishu. International Journal of Education and Social Science Vol. 3 No. 1; January 2016

Apollo Daito, (2007), Metodologi Penelitian Skripsi/Tesis/Disertasi, Universitas Budi Luhur

Colquitt, LePine, Wesson, (2009), Organizational Behavior Improving Performance and Commitment in The Workplace, Mc Graw Hill International Edition

Cooper,Donald, Pamela S Schindler, (2008), Business Research Methods, New York: McGraw Hill, Inc

Cross, T.M dan Lynch. R.R. (2006). Peniliaian dan Evaluasi Kinerja: Konsep dan Praktik. Jakarta. Penerbit Ghalia Indonesia

Dessler, Garry (2007), Manajemen Sumber Daya Manusia, PT. Preshelindo, Jakarta

Emilian Imanda, Diana Sulianti, (2016), Analisis Disiplin dan Kepuasan Kerja Terhadap Kinerja Dengan Motivasi Pegawai Sebagai Variabel Moderating Pada BMT Madani Sidoarjo, FE dan Bisnis UNEJ, Jember.

Fisher, Martin, (2005), Performance Appraisals, Kogan Page Limited

Gilang Ramadhan, (2015), Pengaruh Disiplin Kerja Terhadap Kinerja Pegawai Melalui Motivasi Sebagai Variabel Intervening Pada Balitbang Pemkab Malang, FE dan Bisnis Universitas Muhammadiyah Malang.

Goleman, Daniel, (2008), Emotional Intelligence, Cetakan keenambelas, terjemahan, Gramedia

Hasibuan, Malayu S. P. (2008). Manajemen Sumber Daya Manusia. Edisi Revisi Jakarta: PT. Bumi Aksara

Kleiman, Lawrence S, (2007), Human Resource Management : A Tool For Competitive Advantage, West Publishing Company
Mangkunegara, Anwar, Prabu. (2009). Evaluasi Kinerja SDM, Cetakan 4, Bandung : Refika Aditama

Mathis, Robert L and Jackson, John H, (2006), Manajemen Sumber Daya Manusia, Edisi 10, terjemahan, Salemba Empat

Milkovich, T George and Newman, Jerry M, (2008), Competency, Mc Graw Hill International Edition

Murphy, Kevin R and Cleveland, Jeanette N, (2008), Performance Appraisal : An Organizational Perspective,Colorado State University

Nurchayani, N.M dan Adnyani, I.G.A.D. (2016). Pengaruh Kompensasi dan Motivasi terhadap Kinerja pegawai dengan kepuasan Kerja sebagai Variabel Intervening. EJurnal Manajemen Unud, Vol. 5, No.1, 2016

R Palan, (2008), Competency Manajemen : Teknik Mengimplementasikan Manajemen SDM Berbasis Kompetensi untuk Meningkatkan Daya Saing Organisasi, Seri Manajemen Sumber daya Manusia No.13

Rivai Veithzal, (2009), Manajemen Sumber Daya Manusia untuk Perusahaan dari Teori ke Praktik, RajaGrafindo Persada, Jakarta

Robbins P. Stephen, Coulter Mary alih bahasa oleh Benyamin, (2009), Manajemen, Edisi keenam, Jilid 2, PT. Indeks Jakarta

Rush, Michael dan Althoff, Phillip,(2008). Pengantar Sosiologi Politik. Jakarta: PT. Raja Grafindo Persada

Saeed, S., dan Syah, F.M (2016). Impact of Performance Appraisal on Employee Motivation in Islamic Banking. Arabian Journal of Business and Management Review (OMAN Chapter). Vol. 5, No.7; February

Sedarmayanti. (2009). Good Governance (Kepemerintahan Yang Baik), Bandung : Mandar Maju

Siagian P. Sondang, (2008), Organisasi Kepemimpinan dan Prilaku Organisasi, Gunung Agung Jakarta

Simamora, H. (2004). Manajemen Sumber Daya Manusia. Edisi Ketiga. Yogyakarta: Sekolah Tinggi Ilmu Ekonomi YKPN

Sekaran Umar, (2008), Research Methods For Business, University at Corbandale

Sink, R dan Tuttle, J.K. (2008). Evaluasi Kinerja. Jakarta: Indeks Kelompok Gramedia

Sugiyono. (2004). Metode Penelitian Bisnis. Alfabeta Bandung 
Triton PB (2005), Paradigma Baru Manajemen Sumber Daya Manusia, Tugu Yogyakarta. (2006), SPSS 12.00 Terapan Riset Statistik Parametrik, Andi Yogyakarta.

Wahjosumidjo, (2005), Kepemimpinan dan Motivasi, Liberty Yogyakarta

Wibowo, (2007). Manajemen Kinerja. Cetakan Pertama. Jakarta: Raja Grafindo Persada 